\title{
Tomasz OLEJARZ
}

Państwowa Wyższa Szkoła Wschodnioeuropejska w Przemyślu tomek_olejarz@poczta.fm

\section{Tomasz STĘPNIEWSKI}

Katolicki Uniwersytet Lubelski Jana Pawła II

tomasz.stepniewski5@gmail.com

\section{ZJAWISKO DYSFUNKCJI PAŃSTWA NA PRZYKŁADZIE UKRAINY - ANALIZA PROBLEMOWA}

ABSTRACT Dysfunctional states based on the example of Ukraine - a problem analysis The analysis of Ukraine's dysfunction and dependence, both in national and international dimension, presents a clear picture that the dilemma of whether we are faced with a consolidation of a truly liberal democracy or its non-liberal (hybrid) variety, is still valid. Debates in political sciences are dominated by the view that independent Ukraine ought to be considered a specific case of the so-called "hybrid state". Such countries are characterized by stagnation, corruption, and a dominant position of elites, who offer few benefits to the state and have little public support. In addition, the following are clearly visible in Ukraine: little representation of public interests by state institutions; little political involvement of the society and little social activity in between elections; no respect for regulations of the state under the rule of the law; little public legitimization in elections; little public trust in state institutions/the institution of the state; inadequate operation of the state in general. Therefore, the fact that transformation processes which have been emerging in Ukraine, ought not be considered linear, should be acknowledged. Consequently, describing the character of these processes in view of their complexity and multidimensionality seems more relevant.

Keywords: Ukraine, dysfunctional states, Eastern Europe, Eastern Partnership, Russia 
Słowa kluczowe: Ukraina, państwa dysfunkcjonalne, Europa Wschodnia, Partnerstwo Wschodnie, Rosja

\section{WSTĘP}

We współczesnych stosunkach międzynarodowych specyficzną kategorię pojęciową stanowią państwa dysfunkcyjne. Bardzo często utożsamiane są, nazbyt powierzchownie, z państwami upadłymi. Jednakże w swojej istocie państwo dysfunkcyjne pozostaje suwerennym podmiotem państwowym, zaś „anomalia” jego funkcjonowania dotyczy specyficznych i określonych płaszczyzn jego aktywności, co z kolei niekoniecznie musi oznaczać jego pełnowymiarową degradację funkcjonalną.

Specyficznym przykładem państwa pozostającego w procesie przemian własnej funkcjonalności (dysfunkcji i dependencji) w wybranych płaszczyznach aktywności (wewnętrznej i zewnętrznej) pozostaje Republika Ukrainy. Bezsprzecznie jako najistotniejszy wymiar dysfunkcji współczesnej Ukrainy jawi się szeroki zakres jej zależności (dependencji) od Federacji Rosyjskiej. Głównymi przejawami tejże zależności pozostają: silnie spetryfikowane podobieństwa ustrojowe między oboma państwami, instrumentalne traktowanie ustroju państwa dla doraźnych i partykularnych celów politycznych, jak również bezpośrednie ingerencje Federacji Rosyjskiej w środowisko wewnątrzpolityczne państwa ukraińskiego. W konsekwencji współczesne ukraińskie elity polityczne cechuje głęboki mimetyzm (trwałe naśladownictwo państwa dominującego) i kompradorski charakter (czerpanie korzyści z istnienia asymetrycznej relacji dominacji). W następstwie dla relacji ukraińsko-rosyjskich charakterystyczna pozostaje koncepcja imperializmu strukturalnego, w ramach której elity państwa uzależnionego łączą wspólne interesy z państwem dominującym, nie zaś z własnym społeczeństwem, co stanowi podstawę trwałości relacji dependencji i dysfunkcji w wymiarze całego państwa (Ukraina) ${ }^{1}$.

\section{SPECYFIKA ZJAWISKA DYSFUNKCJI PAŃSTWA}

Państwo, będąc specyficzną formą organizacji życia społecznego, stara się przystosowywać do zmian zachodzących w jego wnętrzu i w środowisku międzynarodowym. Generuje to szereg konsekwencji, zaś jedną z nich stanowi ewolucja dotychczasowego modelu funkcjonowania państwa. Z kolei ewolucja modelu i roli państwa oznacza zasadniczy przełom w funkcjonowaniu stosunków międzynarodowych. Jawi się to jako koniec pewnej epoki, na pewno zaś jako epilog systemu westfalskiego, w ramach którego istnienie suwerennych i stabilnych państw stanowiło conditio sine qua non jego powołania

Por:: A. Szeptycki, Ukraina wobec Rosji. Studium zależności, Warszawa 2013, s. 174-175; także: T. Stępniewski, Polityka bezpieczeństwa Ukrainy po 2010 roku, „Rocznik Instytutu Europy Środkowo-Wschodniej” 2013, R. 11, z. 2: Stowiański trójkąt: Rosja, Ukraina, Biatoruś, s. 143-163. 
i funkcjonowania. Zmianom w funkcjonowaniu państwa immanentnie towarzyszy także współcześnie - zmiana jego ustroju, podziału i sposobu wykonywania władzy, jej ideologicznej legitymizacji, zakresu dostępnych i akceptowanych przez państwo instrumentów stosowanych w polityce wewnętrznej (polityczno-ustrojowej) i międzynarodowej ${ }^{2}$. W rozumieniu tradycyjnym (westfalskim) funkcjonalność państwa określana jest w literaturze przedmiotu jako zdolność sprawowania efektywnej kontroli nad większością terytorium tego państwa oraz ludnością, która je zamieszkuje, utrzymywanie równorzędnych stosunków z innymi państwami oraz sprawowanie rządów prawa, utrzymywanie porządku publicznego etc. Współcześnie po zakończeniu zimnej wojny $\mathrm{w}$ środowisku międzynarodowym wyłonił się pas dysfunkcjonalnych i słabych państw (wąski zakres funkcji państwa przy niskim potencjale instytucjonalnym), uosabiających jakościową zmianę funkcjonalności jego struktur w ich dysfunkcyjność3. Dysfunkcja państwa, w takim ujęciu, oznacza zatem daleko idące osłabienie jego kontroli nad własnym terytorium oraz zamieszkującą je ludnością, przy jednoczesnym obniżeniu (nieraz dramatycznym) efektywności struktur państwa. Co więcej, w wielu przypadkach niewydolność struktur państwowych nie jest wywołana przez absencję lub nieskuteczność rządu, lecz a contrario przez nadmierny rozrost władzy państwa lub nazbyt szeroki zakres jego funkcji (swoista „opuchlizna” instytucjonalna) ${ }^{4}$. Wówczas to przez pojęcie państwa dysfunkcyjnego należy rozumieć podmiot polityczny w kontekście międzynarodowego prawa publicznego (ius inter gentes), który z przyczyn wewnętrznych nie jest w stanie w pełni kontrolować, wykonywać i wykorzystywać atrybutów swojej suwerenności na swym terytorium oraz w stosunkach zewnętrznych ${ }^{5}$.

Co również istotne, procesowi przekształcania się państw w organizmy polityczne określane mianem dysfunkcyjnych sprzyja do pewnego stopnia istniejący w danym momencie historycznym ład międzynarodowy oraz brak wystarczających instrumentów nacisku (perswazji) ze strony innych podmiotów środowiska międzynarodowego. Dlatego też problem dysfunkcji należy rozważać i analizować przez pryzmat dwóch wzajemnie nakładających się czynników: a) ograniczenia podmiotów politycznych pozostających w stanie niedorozwoju strukturalnego i instytucjonalnego; b) panowania lub też istnienia tradycji posiadania przez te podmioty systemu autokratycznego (najczęściej prezydencko-oligarchicznego). Ponadto zachodzi tu zjawisko monizmu

2 Por.: D. Kondrakiewicz, Państwo, [w:] Międzynarodowe stosunki polityczne, red. M. Pietraś, Lublin 2006, s. 66, 90.

3 Por.: G. Gil, Ewolucja funkcji państwa w późnowesfalskim tadzie międzynarodowym, [w:] Późnowestfalski tad międzynarodowy, red. M. Pietraś, K. Marzęda, Lublin 2008, s. 379; R. Rotberg, The Failure and Collapse of Nation-States. Breakdown, Prevention and Repair, [w:] When States Fail: Causes and Consequences, red. tenże, Princeton 2004.

4 Należy zastrzec, iż przyjęta definicja państwa dysfunkcyjnego oznacza jedynie pewną kategorię modelową. W praktyce definicyjnej zaliczenie jakiegokolwiek podmiotu do kategorii „państwa dysfunkcyjnego" jest praktyką relatywnie dyskusyjną i niekiedy zdecydowanie niejednoznaczą, podobnie jak czynienie analogii pomiędzy państwem dysfunkcyjnym a państwem upadtym. Por.: G. Gil, Ewolucja funkcji państwa..., s. 380.

5 R. Włoch, Funkcje polityki zagranicznej, [w: Wstęp do teorii polityki zagranicznejpaństwa, red. R. Zięba, Torun 2004, s. 118-136. 
sfery politycznej, militarnej, gospodarczej i finansowej. W tym przypadku struktury państwowe, zabiegając o rozszerzenie wpływów systemu oligarchicznego, stopniowo przejmują coraz więcej funkcji władczych, aż do osiągnięcia „punktu krytycznego”, po którym rozpoczyna się proces demonopolizacji i delegitymizacji dotychczasowego systemu władzy. W efekcie powstaje organizm dysfunkcyjny, który cechują: słabość funkcjonalna, osłabienie potencjału instytucjonalnego, delegitymizacja władzy, atomizacja społeczeństwa, demonopolizacja władzy administracyjnej i militarnej oraz jego faktyczna deterytorializacja. $Z$ punktu widzenia środowiska międzynarodowego oznacza to: destabilizację regionalną, pojawienie się problemu uchodźstwa oraz atrofię systemu ochrony praw człowieka (łącznie ze zjawiskiem czystek etnicznych i ludobójstwem), a także problem przestępczości transgranicznej oraz dominację zjawisk asymetrycznych (terroryzm międzynarodowy) ${ }^{6}$.

Ponadto jako najistotniejszy z przejawów niewydolności funkcjonalnej państwa jawi się utrata monopolu stosowania prawomocnej siły przez samo państwo, na skutek „prywatyzacji” środków jej użycia, które z kolei przedostają się w ręce innych państw lub podmiotów pozapaństwowych (watażków, grup przestępczych etc.). Współcześnie zatem jednym z największych zagrożeń dla stabilności i bezpieczeństwa systemu międzynarodowego pozostają anonsowane państwa dysfunkcyjne - uosabiające faktyczną próżnię władzy i tworzące nowy rodzaj zagrożeń (asymetrycznych) oraz wyzwań w skali regionów i świata, takich jak: konflikty o niskiej intensywności, transnarodowa przestępczość, migracje, uchodźstwo etc. W następstwie mamy do czynienia z naruszaniem podstawowych atrybutów suwerenności państwa, takich jak: polityka zagraniczna, ekonomiczna, militarna, zaś zjawisko to wiąże się immanentnie z osłabieniem lub wręcz unicestwieniem potencjału instytucjonalnego państwa w płaszczyznach interakcji wewnętrznych i zewnętrznych. Prowadzi to w konsekwencji do zaniku zdolności tworzenia i egzekwowania prawa oraz niewypełniania przez państwo typowych dla niego minimalistycznych funkcji egzystencjalnych ${ }^{7}$.

Zjawisko dysfunkcji państwa opiera się zatem na kilkunastu - subiektywnych z osobna - wskaźnikach zagrożenia państwa, które należy zilustrować na podstawie trzech zasadniczych uwarunkowań, działających jednakże na zasadzie naczyń połączonych: a) sfery publicznej - demografia, procesy migracyjne, zinstytucjonalizowane wykluczenie określonych grup społecznych, religijnych, etnicznych i rasowych, drenaż intelektualistów i naukowców przez inne podmioty; b) czynników ekonomicznych nierównomierny rozwój gospodarczy i podział bogactwa narodowego, permanentna zapaść ekonomiczna, co pociąga za sobą zubożenie oraz wywołuje sytuację rewolucyjną; c) kondycji politycznej instytucji - oligarchizacja i autokratyzacja struktur decyzyjnych, stopniowe pogorszenie się jakości zobowiązań publicznych (służba zdrowia, edukacja, telekomunikacja, transport, kanalizacja), wzrost represyjności danego reżimu

R. Potocki, Państwo dysfunkcyjne w perspektywie geopolitycznej, Geopolityka.org, 13 II 2011, [online] http://www.geopolityka.org/analizy/robert-potocki-panstwo-dysfunkcyjne-w-perspektywiegeopolitycznej, 10 X 2015.

Tamże; A. Ghani, C. Lockhart, Fixing Failed States. A Framework for Rebuilding A Fractured World, New York 2008, s. 124-167. 
i powszechnego naruszania systemu normatywnego, bezkarność służb bezpieczeństwa oraz pojawienie się prywatnych organizacji paramilitarnych (milicji), wzrost tendencji populistycznych i nacjonalistycznych/trybalistycznych oraz obecność wojskowa podmiotów zewnętrznych (siły pokojowe, pomoc humanitarna), choć niekoniecznie konkretnych państw (mogą to także być korporacje wojskowe sponsorowane przez inne podmioty $)^{8}$. Problem w warstwie empirycznej polega zatem na jakości świadczonych przez instytucje państwa usług publicznych oraz osłabieniu zasad samo- i całowładności określonej przestrzeni publicznej, w przeciwieństwie do zjawiska dezagregacji państwa (świadomego ograniczenia segmentów wykonywania władzy centralnej).

Należy jednakże zaznaczyć, iż w tym przypadku podstawowe przyczyny i stopień rozkładu mogą pozostawać zróżnicowane pod względem typu adresata (państwa dysfunkcyjnego). Zwyczajowo przyjmuje się, iż zjawisko to można podzielić na trzy typy: państwo predysfunkcyjne (słabe), państwo paradysfukcyjne (upadające) oraz właściwe państwo dysfunkcyjne (upadłe). Granica między nimi pozostaje zasadniczo nieostra oraz czysto umowna; w praktyce także służy głównie do teoretycznego opisu zastanej rzeczywistości społeczno-politycznej?.

Jak konstatuje Jerzy Zajadło, państwo dysfunkcyjne jest w pewnym sensie swego rodzaju zaprzeczeniem „państwa normalnego”, aczkolwiek w istocie rzeczy nie należy go postrzegać jako li tylko prostą negację klasycznego państwa. Należy jednakże zwrócić uwagę, iż państwo dysfunkcyjne to państwo, w którym na skutek rozpadu struktur państwowych, systemu polityczno-prawnego władza polityczna nie chce lub nie potrafi zapewnić sobie i swoim obywatelom koniecznej stabilizacji, nie jest w stanie pełnić kontroli nad całością swojego terytorium oraz nie potrafi zagwarantować respektowania podstawowych praw człowieka i obywatela ${ }^{10}$. Taką perspektywę przedstawia również Francis Fukuyama, który konstatuje, iż państwa dysfunkcyjne

\section{A. Ghani, C. Lockhart, Fixing Failed States..., s. 17-111.}

9 W literaturze przedmiotu w materii podejmowanych badań nad państwem charakterystyczne jest zjawisko pluralizmu definicyjnego. Dla przykładu, najbardziej popularna typologia państw dysfunkcyjnych obejmuje: państwa słabe (weak state), państwa upadające (failing state), państwa upadłe (failed state) oraz tzw. całkowitą katastrofę państwowości (collapsed state). Por.: J. Milewski, Państwo w Afryce: dylematy i kierunki przeobrażeń [w:] Stosunki międzynarodowe w Afryce, red. J. Milewski, W. Lizak, Warszawa 2002, s. 52-54; S. Bieleń, Państwa upadte, [w:] Organizacja Narodów Zjednoczonych. Bilans iperspektywy, red. J. Symonides, Warszawa 2006, s. 622-639; tenże, Państwa w stanie kryzysu i upadku?, [w:] Państwo w teorii i praktyce stosunków międzynarodowych, red. M. Sułek, J. Symonides, Warszawa 2009, s. 45-64; R. Kuźniar, Polityka i sita. Studia strategiczne - zarys problematyki, Warszawa 2005, s. 266-267, 274-294; M. Piotrkowski, Uwarunkowania oraz konsekwencje rozktadu i rozpadu struktur państwowych, [w:] Pótnoc wobec Potudnia, Potudnie wobec Pótnocy, red. M.W. Solarz, Warszawa 2005, s. 259-268; R. Potocki, Problem rekonstrukcji panstw dysfunkcyjnych na peryferiach systemu światowego po 11 września 2001 r., [w:] Pótnoc wobec Potudnia..., s. 289-301; R. Potocki, M. Kocoń, Państwo dysfunkcyjne w środowisku międzynarodowym, [w:] Państwo w świecie wspótczesnym, red. K. Trzciński, Warszawa 2006, s. 321-335.

10 J. Zajadło, Prawo międzynarodowe wobec problemu „państwa upadtego”, „Państwo i Prawo” 2005, nr 2, s. 3-20; por. R. Potocki, Państwo dysfunkcyjne w perspektywie...; R. Kaplan, Coming Anarchy, „The Atlantic” 1994, nr 2, s. 44-76; Ch. Croker, Engaging Failing States, „Foreign Affairs” 2003, Vol. 82, nr 5, s. 32-45. 
i upadające to jednostki słabe lub niewywiązujące się ze swych podstawowych funkcji społecznych $^{11}$.

Pojęcie państwa dysfunkcyjnego stosowane jest aktualnie zarówno w wąskim, jak i szerokim tego słowa znaczeniu. I tak w znaczeniu procesualnym mianem państwa dysfunkcyjnego można nazwać jeden z etapów procesu degradacji państwa. Najczęściej jednak termin ten używany jest w szerszym znaczeniu (sensu largo), obejmując również państwa, w których nastąpiła całkowita katastrofa państwowości, takie jak państwa upadłe, państwa upadające, a nawet państwa słabe. Ponadto desygnatami stosowanymi na okoliczność procesu definicyjnego w przedmiocie państw dysfunkcyjnych pozostają sformułowania: państwa przeżywające napięcia (states under stress) oraz państwa wychodzące $\mathrm{z}$ konfliktu (countries emerged from conflict) ${ }^{12}$. W tym kontekście należy uwypuklić, iż państwo dysfunkcyjne to podmiot, który niezależnie od posiadanych formalnych atrybutów państwowości (istnienie rządu, wykonywanie czynnego i biernego prawa legacji) nie może lub nie chce wykonywać podstawowych obowiązków wynikających z istoty suwerenności, to znaczy sprawować kontroli nad określonym terytorium, zapewnić minimum praw ochrony życia i zdrowia, jak również powstrzymać się od naruszenia norm prawa międzynarodowego, dotyczących dla przykładu systemu ochrony praw człowieka ${ }^{13}$.

Do niedawna dysfunkcję państwa utożsamiano wyłącznie z państwami biednymi lub, mówiąc szerzej, z problemem niedorozwoju gospodarczego określonych regionów świata. Jednakże współcześnie coraz częściej zjawisko to przenosi się na państwa rozwinięte, zaś kategorię państwa dysfunkcyjnego należy traktować jako signum temporis systemu międzynarodowego XXI w. Według niektórych analiz nawet połowa współczesnych państw jawi się jako „niebezpiecznie słaba” (dysfunkcyjna) ${ }^{14}$. Zdaniem Fukuyamy współczesne państwa dysfunkcyjne stanowią najistotniejsze zagrożenie dla ładu międzynarodowego $\mathrm{w}$ epoce po zakończeniu zimnej wojny ${ }^{15}$, zaś $\mathrm{z}$ punktu widzenia prawnomiędzynarodowego i politycznomiędzynarodowego państwa dysfunkcyjne zostały uznane za te miejsca, w których najintensywniej maksymalizują się "potencjały” godzące w bezpieczeństwo międzynarodowe i wewnątrzpaństwowe. Z kolei do przyczyn wewnętrznych formowania się zjawiska dysfunkcyjności państwa należy przede wszystkim ograniczenie jego funkcji ekonomicznych. Powoduje to upadek więzi społecznych i separatyzm regionów bogatszych, zaś obiektywny niedostatek generuje dalszą defragmentaryzację państwa ${ }^{16}$.

11 F. Fukuyama, Budowanie państwa. Wtadza i tad międzynarodowy w XXI wieku, przet. J. Serwański, Poznań 2005, s. 59-108.

12 Ł. Roman, Państwa upadte jako zagrożenie bezpieczeństwa na początku XXI wieku, „Obronność. Zeszyty Naukowe Wydziału Zarządzania i Dowodzenia AON” 2014, nr 3, s. 117.

13 Por.: Ł. Kulesa, R. Tarnogórski, Przysztość ONZ - reinterpretacja czy zmiana Karty Narodów Zjednoczonych?, „Polski Przegląd Dyplomatyczny” 2005, t. 5, nr 1, s. 48.

14 G. Gil, Ewolucja funkcji państwa..., s. 379; por.: The African Studies Centre, The Transnational Institute, The Peace Studies Group, The Peace Research Center-CIP/FUHEM, Failed and Collapsed States in the International System, Leiden-Amsterdam-Madrid 2003, s. 8-16, 18-21.

15 Por.: F. Fukuyama, Budowanie państwa..., s. 109-136.

16 Por.: A. Ghani, C. Lockhart, Fixing Failed States..., s. 169-195. 
W płaszczyźnie międzynarodowych stosunków politycznych zjawisko dysfunkcji państwa może stanowić pochodną sytuacji jego obiektywnej niestabilności międzynarodowej i obejmować, przede wszystkim, państwa "geopolitycznie osiowe” (np. Ukraina). Wówczas to pomimo iż państwa te tworzą organizmy geopolityczne, spełniające formalne wymogi międzynarodowego prawa publicznego, w praktyce pozostają zaledwie sui generis nie-państwami. Charakteryzuje je atrofia spoistości wewnętrznej, nie spełniają one kryterium posiadania monopolu na stosowanie przymusu i siły fizycznej na własnym terytorium, zaś na ich obszarach panuje stan chronicznej anarchii, permanentnego chaosu oraz wojny wszystkich ze wszystkimi, co w konsekwencji generuje presję takich problemów, jak: trybalizm, ubóstwo, epidemie, kryzysy migracyjne, czystki etniczne i rasowe etc. ${ }^{17} \mathrm{~W}$ środowisku międzynarodowym ich status wydaje się wówczas bardzo niejasny i ograniczony, nade wszystko ze względu na obiektywną słabość polityczno-ekonomiczną, wewnątrzinstytucjonalną oraz relatywnie niską spoistość społeczną. W konsekwencji najczęściej kojarzone są głównie z tzw. „państwami upadtymi”, „państwami-widmami”, „państwami buforowymi” lub wręcz z tzw. „ziemią niczyją" (res nullius) $)^{18}$.

\section{PRZEJAWY DYSFUNKCJI PAŃSTWA NA PRZYKŁADZIE UKRAINY}

\subsection{Płaszczyzna wewnątrzustrojowa}

Istotnym przejawem dysfunkcji państwa w stosunkach międzynarodowych pozostaje jego zależność (dependencja) od innego podmiotu, np. w sferze systemu polityczno-ustrojowego. Wówczas to w tak opisywanej sytuacji system polityczny państwa uzależnionego zostaje niejako „spenetrowany”, czyli poniekąd sterowany od wewnątrz za pośrednictwem instrumentów państwa penetrującego (dominującego). W konsekwencji zmianie ulegają deklarowane interesy państwa spenetrowanego (uzależnionego), zaczyna ono postrzegać środowisko międzynarodowe przez pryzmat interesów podmiotu dominującego, a więc często sprzecznie ze swoją racją stanu (ratio status). Polityka wewnętrzna państwa spenetrowanego staje się w konsekwencji jego polityką zagraniczną, albowiem na własnym terytorium spotyka się z działaniami obcego państwa; natomiast polityka zagraniczna penetratora nabiera cech polityki wewnętrznej, ponieważ jest realizowana wewnątrz państwa poddanego penetracji. Przy czym nie ma jednoznacznej odpowiedzi na pytanie, czy koniecznym elementem relacji zależności w sferze systemu politycznego jest faktyczne przejęcie przez państwo uzależnione rozwiązań ustrojowych istniejących w państwie dominującym. W praktyce jednakże państwo dominujące staje się dla przywódców i elit politycznych państwa uzależnionego

R. Potocki, Państwo dysfunkcyjne w perspektywie...

18 Tamże; R. Cooper, Pękanie granic. Porzadek i chaos w XXI wieku, przeł. P. Kłossowicz, Poznań 2005, s. 37-39; F. Fukuyama, Budowanie państwa..., s. 59-108; R. Kaplan, The Coming Anarchy. Shattering the Dreams of the Post-Cold War, New York 2000, s. 3-57, 99-102, 111-117. 
swoistym wzorcem i modelem postępowania, co też wynika ze względów obiektywnych, jak i subiektywnych, charakterystycznych dla stanu istniejącej dependencji pomiędzy podmiotami ${ }^{19}$.

I tak najważniejszymi przejawami zależności Ukrainy od Federacji Rosyjskiej, wpływającymi na stan dysfunkcji państwa ukraińskiego na płaszczyźnie polityczno-ustrojowej, stały się podobieństwa ustrojowe pomiędzy oboma podmiotami, będące przynajmniej po części następstwem naśladownictwa rosyjskich (i sowieckich) rozwiązań ustrojowych, ale także subiektywnego przekonania większości przedstawicieli ukraińskiego systemu politycznego o potrzebie i znaczeniu współpracy z Rosją w materii polityczno-ustrojowej, jak również egzemplifikacje bezpośrednich ingerencji Federacji Rosyjskiej w środowisko wewnątrzpolityczne Ukrainy, zmierzające do wsparcia tych podmiotów politycznych w tym państwie, które były postrzegane w Rosji jako co najmniej przyjazne ${ }^{20}$.

Z perspektywy uwarunkowań historycznych należy zauważyć, iż bez wątpienia Ukraina i Rosja przeszły po rozpadzie ZSRR podobną ewolucję ustrojową. W pierwszym okresie w środowisku wewnętrznym obu państw ukształtował się system polityczny określany mianem demokracji delegowanej ${ }^{21}$. Charakteryzowały go niejasny podział kompetencji i chroniczne zjawisko dysfunkcji ustrojowej, przejawiające się w konfliktach kompetencyjnych pomiędzy głównymi ośrodkami władzy ustawodawczej i wykonawczej, jak również alienacja większości społeczeństwa od władzy z jednoczesną wielowymiarową zależnością od niej samej; jednostronne podporządkowanie obywateli normom i regułom oraz realizowanie przez państwo swoich uprawnień bez jakiejkolwiek zewnętrznej kontroli; brak realnych gwarancji poszanowania systemu ochrony praw człowieka i obywatela, a tym samym postępująca bezsilność przeciętnego obywatela wobec władzy urzędników; niejasne przemiany w sferze gospodarczej, rozdysponowanie ogólnonarodowej własności w czasie panowania grup biznesowo-klanowych; połączenie skorumpowanej władzy politycznej, szarej strefy gospodarczej i świata kryminalnego; dominacja klanów nomenklaturowo-korporacyjnych, faktyczna symbioza struktur oligarchicznych i politycznego autorytaryzmu; partykularne wykorzystanie przez oligarchów norm i procedur prawno-demokratycznych ${ }^{22}$.

W konsekwencji zarówno Ukraina, jak i Rosja zaczęły na początku lat 90. ewoluować ku tzw. rywalizacyjnemu autorytaryzmowi, w ramach którego formalnie obowiązywały mechanizmy demokratyczne, niemniej w praktyce miały one charakter fasado-

19 A. Szeptycki, Ukraina wobec Rosji..., s. 66; Z.J. Pietraś, Polityka zagraniczna państwa, [w:] Wspótczesne stosunki międzynarodowe, red. T. Łoś-Nowak, Wrocław 1997, s. 64.

20 A. Szeptycki, Ukraina wobec Rosji..., s. 112.

21 Tamże, s. 125.

22 T. Olejarz, T. Stępniewski, Ukraina między dysfunkcjonalna demokracja a nieskonsolidowanym autorytaryzmem, Lublin 2011, s. 26, Prace Instytutu Europy Środkowo-Wschodniej, 23; ciż, Украина между дисфункииенаальой демократией а несконсолидированньцм авторитаризмом, [w:] Перед выбором. Будущее Украиньь в условиях системной дестабилизачии, red. А. Гиль, Т. Стемпневски, Lublin 2013, s. 73-74; por.: J. Macijewskij, Między autorytaryzmem i demokracja: ustrój polityczny w Ukrainie po „pomarańczowej rewolucji”, „Nowa Ukraina” 2008, nr 1-2, s. 15-151. 
wy i były skutecznie omijane i łamane ${ }^{23}$. Co najmniej od połowy lat 90. w środowisku ukraińskich intelektualistów pojawiały się jednakże opinie, iż deklarowane cele konstytucyjno-ustrojowe nie odpowiadają codziennej praktyce politycznej na Ukrainie. W okresie późniejszym zostały one podzielone także przez znaczną część obywateli ukraińskich. Wśród niewielkiej liczby naukowców zajmujących się badaniem ukraińskiego ustroju politycznego nie istniały zatem żadne wątpliwości co do braku faktycznej demokratyzacji na Ukrainie. I tak np. Wołodymyr Połochało zaproponował tezę o neototalitarnym charakterze ustroju politycznego ówczesnej Ukrainy ${ }^{24}$. Co istotniejsze, chronologia wydarzeń politycznych na Ukrainie i w Federacji Rosyjskiej potwierdzała, iż ewolucja rosyjskiego systemu politycznego postępowała szybciej aniżeli na Ukrainie, co pozwalało skonstatować, iż FR pozostawała, przynajmniej po części, modelem „rozwojowym” dla ukraińskiego państwa. Przyznawał to poniekąd ówczesny prezydent Ukrainy Leonid Kuczma. Na szczególną uwagę zasługują w tym kontekście wybory prezydenckie w Rosji z 1996 r. i te na Ukrainie z 1999 r. oraz „namaszczenie” następcy przez Borysa Jelcyna (1999 r.) i Leonida Kuczmę (2004 r.). To, co jedynie różniło oba państwa, to fakt, iż na Ukrainie nie doszło do siłowej konfrontacji pomiędzy organami władzy, jak w Rosji w 1993 r., natomiast w Federacji Rosyjskiej nie doszło do wydarzeń z pogranicza „pomarańczowej rewolucji”.

W latach 2005-2010 oba państwa rozwijały się na płaszczyźnie ustrojowej w odmienny sposób, aczkolwiek już po wyborach prezydenckich na Ukrainie 2010 r. oba podmioty ponownie upodobnity się pod tym względem: ukraiński system polityczny zaczął ponownie ewoluować w kierunku modelu autorytarnego; w Rosji w 2012 r. na stanowisko prezydenta powrócił po czteroletnim „interludium” Władimir Putin ${ }^{25}$.

Jak zauważa Andrzej Szeptycki, analiza ewolucji sytuacji ustrojowej Ukrainy i Rosji w latach 1991-2012 prowadzi do trzech zasadniczych wniosków. Po pierwsze, polityka zagraniczna obu państw, a w efekcie również ich wzajemne stosunki miały charakter silnie spersonalizowany. Wynikało to zarówno z poradzieckich rozwiązań ustrojowych i tradycji politycznych, jak i z ogólnej ewolucji współczesnego pozimnowojennego ładu międzynarodowego, w ramach którego coraz większą rolę odgrywały niejednokrotnie osobiste relacje między poszczególnymi decydentami. Po drugie, możemy mówić o naśladownictwie (mimetyzmie) rosyjskich rozwiązań ustrojowych przez ukraińskie elity polityczne. Naśladownictwo to miało charakter fluktuatywny. W Rosji w 2000 r. ukształtował się skonsolidowany system autorytarny, natomiast na Ukrainie niedemo-

A. Szeptycki, Ukraina wobec Rosji. Studium..., s. 125-126.

24

В. Полохало, Політична арена України, „Філософська і соціологічна думка” 1992, nr 4; tenże, Метаморфози посткомуністичної влади, „Сучасність” 1996, nr 9; tenże, Політологія посткомуністичних суспільств в Україні та Росї, „Політична думка” 1998, nr 2, s. 17-18.

25 A. Szeptycki, Ukraina wobec Rosji..., s. 126-127; A. Riabow, Rosja i Ukraina - dwa alternatywne modele transformacji postkomunistycznej?, [w:] Rosja: jak żyć z Ukraina? Ukraina: jak żyć z Rosją? Stosunki ukraińsko-rosyjskie w 2006 roku i w najbliższej przysztości, red. W. Konończuk, Warszawa 2006, s. 5-11; J. Hughes, Transition Models and Democratisation in Russia, [w:] Russia after the Cold War, red. M. Bowker, C. Ross, Harlow 2000, s. 44-45; I. Way, Authoritarian State Building and the Source of Regime Competitiveness in the Fourth Wave: The Cases of Belarus, Moldova, Russia, and Ukraine, „World Politics” 2005, Vol. 57, nr 2, s. 231-261, [online] http://dx.doi.org/10.1353/wp.2005.0018. 
kratyczne rządy napotkały sprzeciw społeczny, czego przykładem jest „pomarańczowa rewolucja”. Po trzecie, podobieństwa ustrojowe pozostawały istotnym elementem zbliżającym oba podmioty i pozwalającym potencjalnie skutecznie wpływać Rosji na Ukrainę. Zaistniała bowiem korelacja pomiędzy polityką wewnętrzną i zagraniczną Ukrainy. Autorytaryzm w polityce wewnętrznej na Ukrainie łączył się ze zbliżeniem z Rosją (Leonid Kuczma, 1999-2005; Wiktor Janukowycz 2010-2014), podczas gdy rodząca się demokracja w tym państwie prowadziła do pogorszenia relacji z rosyjskim sąsiadem (Wiktor Juszczenko, 2005-2010; Petro Poroszenko, 2014-) ${ }^{26}$.

Istotną cechą (differentia specifica) charakterystyczną dla podejmowanych i realizowanych reform konstytucyjnych na Ukrainie zawsze pozostawała walka o władzę. Poprawki do konstytucji wnoszono najczęściej w warunkach braku stabilizacji ustrojowej i w atmosferze zwalczających się podmiotów partyjnych i permanentnych fluktuacji politycznych oraz ingerencji ze strony Federacji Rosyjskiej ${ }^{27}$. W procesach konfrontacji wewnątrzpolitycznej na Ukrainie ingerencje Rosji miały przede wszystkim na celu wspieranie tych polityków, którzy byli postrzegani jako przychylni FR, i a contrario osłabianie tych, których program polityczny uważany był za sprzeczny z interesami rosyjskimi (np. Julia Tymoszenko). Działania władz rosyjskich miały charakter zarówno bezpośredni (wykorzystanie instrumentów o charakterze politycznym), jak i pośredni (zastosowanie instrumentów gospodarczych, kulturalnych itp.). Najbardziej emblematyczne przejawy ingerencji FR w wewnętrzne sprawy Ukrainy obejmowały i dotyczyty m.in.: poparcia FR dla prezydenta Leonida Kuczmy; zaangażowania Rosji w wybory prezydenckie 2004 r.; działania bezpośrednio wymierzone przeciwko prezydentowi Wiktorowi Juszczence; działania FR wobec wydarzeń „rewolucji godności” 2014 r. oraz działania związane z procesem aneksji Krymu i faktycznej dezintegracji terytorialnej wschodniej części państwa ukraińskiego w ramach działań militarnych (operacyjnych) wspierających separatyzm Republik Ługańskiej i Donieckiej ${ }^{28}$.

Efektywność opisywanej ingerencji FR do dziś oceniana jest niejednoznacznie. $\mathrm{Z}$ jednej strony władzom rosyjskim nie udało się np. zapewnić zwycięstwa Janukowycza w 2004 r., aczkolwiek działania wymierzone przeciwko Juszczence utrudniły mu przeprowadzenie w sposób efektywny niezbędnych reform wewnętrznych (faktyczna dysfunkcja polityczno-ustrojowa państwa) i prowadzenie bardziej niezależnej od Rosji polityki zagranicznej, co ważniejsze, nie udało się FR na trwale zdezintegrować struktury terytorialnej państwa ukraińskiego (jako państwa unitarnego) po wydarzeniach „rewolucji Euromajdanu”. Z drugiej strony ciągle istniejące zależności w sferze systemu politycznego (elementy trwałości) generowały - do dnia dzisiejszego - negatywne (dysfunkcyjne) konsekwencje dla państwa ukraińskiego, tj. utrudniające wprowadzenie na Ukrainie rozwiązań ustrojowych i praktyki politycznej zgodnej ze standardami Unii Europejskiej oraz ograniczające możliwość rozwoju współpracy z innymi pod-

\footnotetext{
26 A. Szeptycki, Ukraina wobec Rosji..., s. 127-128.

27 T. Olejarz, T. Stępniewski, Ukraina między dysfunkcjonalna demokracją..., s. 31; ciż, Украина междy дисфункииёнальной демократией..., s. 74.

28 Por.: A. Szeptycki, Ukraina wobec Rosji..., s. 162-174.
} 
miotami w środowisku międzynarodowym. W tym miejscu należy uwypuklić specyfikę współzależności dwóch anonsowanych problemów, tj. autorytarna polityka wewnętrzna (Kuczma, Janukowycz) zmusiła ukraińskich przywódców politycznych do szukania wsparcia Rosji; Federacja Rosyjska godziła się na to w zamian za sprzyjające jej działania podejmowane przez Ukrainę w sferze jej polityki zagranicznej. W przeszłości istniejące zależności w sferze systemu politycznego przynosiły Ukrainie także pewne korzyści, np. ustępstwa Rosji wobec Ukrainy w przedmiocie importu i wysokości cen rynkowych za węglowodory ${ }^{29}$.

Zasadniczy etap społecznej weryfikacji pryncypiów ustrojowych niepodległej Ukrainy przypadł na okres schyłkowy roku 2004 i 2014. Został on sprokurowany nowymi realiami, w jakich znalazło się społeczeństwo i państwo ukraińskie na skutek wyborów prezydenckich 2004 r. i tzw. "pomarańczowej rewolucji” ${ }^{30}$ trwającej od 22 listopada 2004 r. do 23 stycznia 2005 r. oraz odmowy podpisania przez ówczesnego prezydenta Ukrainy Wiktora Janukowycza umowy stowarzyszeniowej z Unią Europejską 21 li-

29 Por.: tamże, s. 173-174.

30 Wśród większości ukraińskich badaczy i niektórych zachodnich uczonych utrwalił się pogląd, że wydarzenia z listopada-grudnia 2004 r. należy uznać za rewolucję. W tym kontekście zauważono, iż wykorzystanie pojęcia rewolucji politycznej przez ukraińskich politologów było uwarunkowane potrzebą uzasadnienia rewolucyjności tychże wydarzeń, pomimo realnego braku oznak konfrontacji i przemocy. Rewolucja polityczna, w interpretacji W. Jakuszyka i A. Kołodija, przyjmuje postać swoistego eufemizmu, który określa polityczny przewrót, jaki miał wówczas miejsce. Jednakże ani rewolucja, ani przewrót na Ukrainie faktycznie nie nastąpiły. Wydarzenia z listopada-grudnia $2004 \mathrm{r}$. bardziej poprawnie należy uznać za akcję politycznego protestu na dużą skalę, zaplanowaną przez liderów opozycji i popartą przez znaczną część obywateli Ukrainy, w rezultacie czego doszło do upadku autorytarnego reżimu L. Kuczmy. Należy również dodać, że ostatecznym potwierdzeniem tego, że wydarzeń z końca 2004 r. nie należy rozpatrywać jako rewolucji, nawet tej politycznej, jest to, że nowej ekipie rządowej nie udało się zmienić reguł sprawowania władzy i ustroju politycznego państwa ukraińskiego. Dlatego też należy przyjąć, że omawiane wydarzenia miały pewne cechy rewolucyjności (kryzys polityczny, który trwał od ogłoszenia rezultatów drugiej tury wyborów do decyzji Sądu Najwyższego o anulowaniu jej wyników i wyznaczenia dodatkowego głosowania, polityczna mobilizacja znacznej części obywateli, konfrontacja władzy i opozycji, polityczna polaryzacja w społeczeństwie), aczkolwiek nie daje to podstaw do uznania ich za rewolucję sensu stricto. Wydarzenia te nie były także puczem rozumianym i opisywanym przez pryzmat tzw. tranzytologii. W tej specyficznej gałęzi badań politologicznych wyodrębnia się kilka typów politycznej transformacji: reforma, rewolucja, przewrót, przejście/przemiana (in transition). Jeśli rewolucja stanowi przebudowę istniejących instytucji władzy za pomocą przemocy, to przejście/przemiana stanowi taki typ politycznej transformacji, dla którego charakterystyczna pozostaje zmiana instytucji bez potrzeby naruszania norm prawnych. Reforma i przewrót również nie spełniają tych warunków w kontekście wydarzeń na Ukrainie. Z tego punktu widzenia należy przyjąć, iż na Ukrainie miała miejsce pokojowa zmiana rządzącej elity, dzięki masowemu udziałowi społeczeństwa w politycznym nieposłuszeństwie w okresie prezydenckiej kampanii wyborczej. Innymi słowy, była to swego rodzaju rotacja elit, która prima facie mogła wyglądać na obalenie reżimu, jednakże demokratyczny impuls „pomarańczowej rewolucji” nie doprowadził do oczekiwanych zmian jakościowych, przede wszystkim w sposobie sprawowania władzy. Wśród pozytywnych czynników należy jednak dostrzec: umocnienie konkurencji politycznej i pluralizmu politycznego, wolności środków masowego przekazu, ukształtowanie wśród mieszkańców większości regionów postaw obywatelskich, wzrost pozytywnej dynamiki w polityce wewnętrznej i zewnętrznej państwa ukraińskiego. Por.: T. Olejarz, T. Stępniewski, Ukraina między dysfunkcjonalną demokracją..., s. 38; сіż, Украина между дисфункииёнальной демократией..., s. 81-82; J. Macijewskij, Między autorytaryzmem i demokracja..., s. 154-158; A. Åslund, How Ukraine Became a Market Economy and Democracy, Washington 2009, s. 175-199. 
stopada 2013 r., co skutkowało wydarzeniami potocznie określonymi mianem „rewolucji godności” lub „rewolucji Euromajdanu”, trwającymi między 21 listopada 2013 r. a 23 lutego $2014 \mathrm{r}^{31}$ Społeczno-politycznych charakter i istota opisywanych wydarzeń

31 Proces tranzycji władzy na Ukrainie, trwający na przełomie 2013 i 2014 r., potocznie określany mianem „rewolucja godności” i „Euromajdan”, charakteryzował się określonymi fazami ewolucji i pozostawał uwarunkowany poziomem represyjności działań podejmowanych przez władzę rządzącą i podległe jej organy bezpieczeństwa. Socjologowie prowadzący badania wśród uczestników kijowskiego „Euromajdanu” wyróżnili trzy fazy jego przebiegu. Pierwsze stadium określono mianem Majdanu-mityngu. Jest to okres do pierwszej połowy grudnia 2013 r., zaś jego treść stanowiły protesty spowodowane niepodpisaniem przez prezydenta umowy stowarzyszeniowej z UE w Wilnie oraz brutalne pobicie bezbronnych studentów w nocy z 29 na 30 XI 2013 r. Koniec grudnia to czas funkcjonowania Majdanu-obozu, kiedy to protestujący zamieszkali na Majdanie Niepodległości. Strona rządowa nie podejmowała wówczas zakrojonych na szeroką skalę brutalnych działań zaczepnych. Trzecim stadium okazał się tzw. Majdan-Sicz (odwołujący się do tradycji Siczy Zaporoskiej). Majdan-Sicz stał się, głównie w lutym 2014 r., areną regularnych starć między manifestantami a funkcjonariuszami służb porządkowych i wojsk wewnętrznych podporządkowanych prezydentowi Janukowyczowi i obozowi władzy. W tym kontekście należy uwypuklić, iż opinię publiczną oraz ekspertów, nie tylko w Polsce, ale także w Europie i na świecie, od początku protestów podejmowanych na Ukrainie żywo interesował problem reprezentacji społecznej tzw. „Euromajdanu”. Jako istotne jawiły się również pytania o charakter i celowość podejmowanych działań, mających pozostawać dla sceptyków próbą obalenia istniejącego ładu konstytucyjnego w państwie, tym razem przez radykalną i znajdującą się w mniejszości zorientowaną proeuropejsko część społeczeństwa ukraińskiego, oraz dylematy dotyczące zakresu legitymizacji społecznej niezbędnej dla „prawomocności politycznej i moralnej” tychże demonstracji. Zdaniem ukraińskiej socjolog, dyrektor Fundacji Demokratyczne Inicjatywy Iryny Bekeszkinej Majdan reprezentowat catą Ukrainę, choć najwięcej osób wywodzito się z jej zachodniej i centralnej części. Co się zaś tyczy imperatywów i celów motywacyjnych demonstracji, to w swoich początkowych fazach „Euromajdan” miał na celu wymuszenie na stronie rządzącej podpisania umowy o stowarzyszeniu z UE. Zasadniczo sytuację zmieniło pobicie manifestujących bezbronnych studentów przez oddziały Berkutu w nocy 30 XI 2013 r. Wydarzenie to spowodowało, iż manifestacje o początkowo charakterze proeuropejskim i prounijnym przekształciły się w protest antyrządowy na szeroką skalę. Socjologowie, zapytawszy respondentów o ich motywacje i cele, wyodrębnili trzy najważniejsze powody uczestnictwa: brutalne represje władzy przeciwko uczestnikom protestów; niepodpisanie przez W. Janukowycza umowy stowarzyszeniowej z UE; oraz pragnienie dokonania jakościowej zmiany życia na Ukrainie. Znamienne, iż głównym celem i motywacją manifestantów pozostawała chęć zmiany nie tyle samej władzy, co sposobu jej sprawowania. Stowarzyszenie z UE traktowane było z jednej strony jako symbol demokracji i lepszego życia, z drugiej - jako instrument, który zmusiłby elity polityczne do zmiany stylu rządzenia oraz poszanowania podstawowych praw obywateli. Symptomatyczne, iż wśród powodów wyjścia na Majdan bardzo rzadko wskazywano na apele czołowych polityków opozycji parlamentarnej. Apolityczność Majdanu, szczególnie we wczesnym jego stadium, zauważają autorzy opracowania z Ośrodka Studiów Wschodnich - W. Konończuk i T.A. Olszański. „Euromajdan” początkowo miał charakter świadomie antypartyjny, zaś na wiecach dostrzec można było jedynie ukraińskie flagi narodowe i flagę Unii Europejskiej. Za symboliczny można uznać fakt, iż początkowo obok siebie funkcjonowały dwa „Euromajdany”: pierwszy - na Majdanie Niepodległości, zorganizowany oddolnie, w sposób nieformalny, przez aktywistów społecznych i studentów, oraz drugi - zawiązany przez liderów opozycji parlamentarnej na Placu Europejskim, oddalonym od pierwszego o kilkaset metrów. Do ich połączenia, a raczej do przyłączenia „Euromajdanu opozycji” do „Euromajdanu aktywistów i studentów", doszło 26 XI 2013 r. Trzej czołowi liderzy opozycji parlamentarnej: A. Jaceniuk, W. Kliczko i O. Tiahnybok stali się od tej pory oficjalnie głosem Majdanu, jednak nigdy nie zyskali pełnego poparcia ani zaufania jego uczestników. Zdaniem autorów wspomnianego raportu OSW zabrakło jednego silnego lidera Majdanu, który mógłby cieszyć się takim autorytetem, jak to było podczas „pomarańczowej rewolucji” w 2004 r. Skutkiem tego były problemy w komunikowaniu i artykułowaniu oczeki- 
przełomu 2004 i 2014 r. i związany z nimi polityczny proces tranzycji władzy doprowadziły do ponownej redefinicji systemu politycznego na Ukrainie, tym razem w kierunku parlamentarnej formy rządów.

W tym miejscu należy uwypuklić, iż dylematy związane z procesem kształtowania systemu politycznego i wyboru jego odpowiedniego modelu nie okazały się li tylko wyłącznie „fenomenem” Ukrainy, albowiem zdecydowana większość państw byłego ZSRR do dnia dzisiejszego boryka się z problemami związanymi z poszukiwaniem właściwego modelu polityczno-ustrojowego. Tak ukształtowane reżimy polityczne (o hybrydowym charakterze) okazały się na tyle trwałe, iż obecnie zaliczane są do kategorii tzw. demokracji nieskonsolidowanych i pozostają differentia specifica tego regionu (obszar poradziecki). Innymi słowy, dla Ukrainy, Mołdawii czy Białorusi rozpad ZSRR oznaczał początek długotrwałego okresu przejściowego, w ramach którego odbywają się permanentne poszukiwania właściwej formuły ustrojowej, ze wszystkimi tego pozytywnymi i negatywnymi implikacjami.

W szczególności dla Ukrainy oznaczało to ponadto, iż odzyskanie suwerenności przez elity polityczne i społeczeństwo nie stanowiło niestety początku procesu głębokich przekształceń w sferze kultury politycznej i kształtowania jej jakości, od której charakteru miały zależeć in spe specyfika, trwałość i siła ukraińskiej demokracji oraz jej międzynarodowa wiarygodność. Ten fakt z kolei miał stanowić o przebiegu, tempie i efektach podejmowanych na Ukrainie przekształceń ustrojowych, społeczno-gospodarczych i cywilizacyjno-kulturowych.

Co ważniejsze, w podejmowanej praktyce politycznej oznaczało to, iż u progu ukraińskiej niepodległości podejmowanie decyzji o kształcie tworzonych instytucji, sposobie ich przekształcania oraz egzekwowania za ich pośrednictwem uprawnień władzy politycznej okazało się de facto awykonalne, ponieważ Ukraina nadal pozostawała (pozostaje?) pod względem standardów ustrojowych państwem sowieckim. Jedyną istotną

wań demonstrantów na określonych etapach procesu „Euromajdanu”. Konkludując, należy stwierdzić, iż oparta na badaniach socjologicznych charakterystyka procesu „Euromajdanu” oraz jego porównanie z opisywanymi przez M. Castellsa rewolucjami cyfrowymi, rizomatycznymi, w społeczeństwie sieci pozwala myśleć o „Euromajdanie” jako sui generis reprezentacji całego społeczeństwa ukraińskiego. Umożliwia uchwycenie jego różnorodności oraz tego, co wspólne i zarazem specyficzne i wyjątkowe. Innymi słowy, umożliwia postrzeganie procesu „Euromajdanu” jako protestu oddolnego, zorientowanego na wartości, nie zaś na lidera społecznego czy politycznego (w przeciwieństwie do „pomarańczowej rewolucji” w 2004 r.). Istotna pozostaje również struktura zdecentralizowana, horyzontalna, nie zaś wertykalna analizowanego protestu, czego symbolem jest demokratyczny, wirtualny, internetowy wymiar opisywanej formy mobilizacji i w okresie późniejszym obywatelskiego sprzeciwu. Co najważniejsze, siłą napędową procesu „Euromajdanu” oraz jego symbolami stali się ludzie młodzi, aktywni, mobilni, przedsiębiorczy i umiarkowani, mający ambicje, aby stać się częścią nowej ukraińskiej klasy średniej i być może w przyszłości również elity polityczno-ideowej tego państwa. Por.: A. Jekaterynczuk, Kogo reprezentowat kijowski Majdan 2013-2014? Struktura spoteczno-demograficzna i kulturowa kijowskiego Euromajdanu w Kijowie, oczekiwania oraz ewolucja. Socjologiczny obraz kijowskiego Majdanu z końca 2013 - początku 2014 roku, „Rocznik Instytutu Europy Środkowo-Wschodniej” 2014, R. 12, z. 5: Rosja Putina-Ukraina-Europa: geopolityka, bezpieczeństwo, gospodarka, s. 157-179; W. Konończuk, T. Olszański, Co Majdan mówi o Ukrainie? Diagnoza i perspektywy ukraińskiej polityki, 17 I 2014, Komentarze OSW, nr 125, [online] http://www.osw.waw.pl/pl/publikacje/komentarze-osw/2014-01-17/co-majdan-mowi-o-ukrainie-diagnoza-i-perspektywy-ukrainskiej, 10 X 2015. 
i realną zmianą stało się zniesienie aparatu partii komunistycznej jako nadrzędnej struktury władzy, aczkolwiek pozostałe struktury biurokratyczne pozostały bez zmian, przez co także bez koniecznej kontroli, co sprzyjało faktycznemu chaosowi i dysfunkcji państwa, zaś same zmiany przyjęły charakter minimalistyczny i powierzchowny ${ }^{32}$.

W konsekwencji proces instytucjonalizacji ustroju politycznego ograniczał się de iure tylko do formalnego zadekretowania w ustawach zasadniczych przyjętych rozwiązań prawnoustrojowych, zaś elementem konstytutywnym nie stała się niestety gotowość aparatu państwa i elit politycznych do wykorzystania instytucji państwa i funkcjonujących mechanizmów prawnych na rzecz deklarowanych wartości, tj. jeszcze głębszej demokratyzacji Ukrainy. W tym sensie należy skonstatować, iż metaforycznie rzecz ujmując, ukraińska niepodległość dość mocno zaskoczyła polityczne i administracyjne elity rządzące (centralne i lokalne). W konsekwencji realną władzę polityczną na Ukrainie w latach 1991-2004 sprawowała nieformalna koalicja, złożona w dużej części z dotychczasowej nomenklatury postsowieckiej i skromnej części prawicowych ugrupowań, dążących za wszelką cenę do utrzymania ukraińskiej niepodległości. Ten specyficzny układ sił, powstały w imię ukraińskiej niepodległości, stał się w okresie późniejszym przyczyną wielu negatywnych zjawisk charakterystycznych dla systemu politycznego Ukrainy („rewolucja Euromajdanu” i separatyzm tzw. Republik Donieckiej i Ługańskiej).

Konkludując, należy stwierdzić, iż dotychczasowe próby zmiany reżimu politycznego na Ukrainie (przede wszystkim na formułę systemu parlamentarnego, tj. w latach 2000, 2004, 2014?) dokonywane były w warunkach trwałego politycznego kryzysu. Ponadto dodatkowym celem podejmowanych działań niestety nie miały stać się ani wprowadzenie nowego (lepszego i bardziej funkcjonalnego) reżimu politycznego jako kolejnego kroku w procesach demokratyzacji państwa, ani swego rodzaju „fascynacja” elit politycznych na Ukrainie pogłębiającym się parlamentaryzmem, zaś opisywana pragmatyka miała tylko i wyłącznie służyć faktycznej petryfikacji i utrzymaniu aparatu wykonawczego przez dominujący w danym momencie historycznym polityczny obóz władzy (tzw. problem instrumentalizacji ustroju państwa dla doraźnych i wąskopartykularnych celów politycznych) ${ }^{33}$.

\subsection{Płaszczyzna środowiska międzynarodowego}

Najważniejszymi przejawami zależności Ukrainy od Federacji Rosyjskiej, wpływającymi na zjawisko i stan dysfunkcji i dependencji państwa ukraińskiego na płaszczyźnie polityczno-międzynarodowej, pozostają ścisłe i spluralizowane więzi zależności łączące Ukrainę z Rosją, przede wszystkim w sferze polityki zagranicznej. W tym kontekście należy w pierwszej kolejności wymienić jako czynnik warunkujący specyfikę treści polityk zewnętrznych obu podmiotów obiektywnie odmienną pozycję każdego

32 Por.: K. Fedorowicz, Ukraińskie rewolucje a parlamentaryzm, „Rocznik Instytutu Europy Środkowo-Wschodniej" 2014, R. 12, z. 2: Majdan 2014: Ukraina na rozdrożu, s. 57-59.

33 Tamże, s. 59-62, 70-71. 
z nich (państw) w środowisku międzynarodowym ${ }^{34}$. Federacja Rosyjska jako sukcesorka i depozytariuszka ZSRR pozostała, pomimo istniejących w jej środowisku wewnątrzpolitycznym głębokich ograniczeń, mocarstwem globalnym. Ukraina dla odmiany pozostaje jednym z państw, które po rozpadzie ZSRR znalazły się w tzw. „szarej strefie” bezpieczeństwa („próżnia geopolityczna”) między Rosją a poszerzonymi UE i NATO ${ }^{35}$. W konsekwencji, w warunkach faktycznej asymetrii pozycji obu państw i ich obiektywnych potencjałów, jak również odmiennego „nowego” położenia geopolitycznego, istotną rolę we wzajemnych interakcjach Ukraina-FR odgrywa nieustannie treść ich polityk zagranicznych, realizowanych zarówno w płaszczyźnie stosunków bilateralnych, jak i w szerszym kontekście regionalnym całego obszaru Europy Środkowo-Wschodniej.

Nie ulega zatem wątpliwości, iż jak wspominano uprzednio, obszar Europy Środkowo-Wschodniej po 1989 r. znalazł się w tzw. „geopolitycznej szarej strefie” lub też faktycznej „próżni bezpieczeństwa”36. W takich właśnie warunkach nowego pozimnowojennego środowiska międzynarodowego (pozostającego w regionie Europy Środkowo-Wschodniej na etapie in statu nascendi) 24 sierpnia 1991 r. Rada Najwyższa

34 Pozycja Ukrainy w stosunkach międzynarodowych (bez względu na to, czy zajmuje miejsce centralne, czy też peryferyjne - z naciskiem na to drugie) warunkuje treść roli międzynarodowej, jaką państwo ukraińskie odgrywa w środowisku międzynarodowym. Ze względu na kluczowe położenie geograficzne Ukrainy (pomiędzy Wschodem i Zachodem) posiadaniem stref wpływów na jej obszarze zainteresowanych jest wiele państw i podmiotów pozapaństwowych. Dlatego też od jakości i aktywności „dyplomacji” ukraińskiej zależy w pierwszej kolejności stan stosunków politycznych w szerokiej konstelacji państw regionu Europy Środkowo-Wschodniej en masse. Należy przy tym podkreślić, iż niepodległa i stabilna wewnętrznie Ukraina to najlepsza gwarancja hamowania neoimperialnych tendencji, przede wszystkim ze strony Federacji Rosyjskiej. Dlatego też niezwykle ważne jest tzw. „zachowawcze nastawienie" Ukrainy w płaszczyźnie polityki zagranicznej, czyli faktyczne utrzymywanie stanu stabilnej równowagi politycznych wpływów na jej terytorium, pomiędzy: Unią Europejską, Stanami Zjednoczonymi i Federacją Rosyjską. Z drugiej strony należy uwydatnić, iż geopolityczne położenie komplikuje państwu ukraińskiemu kreowanie podmiotowej i suwerennej polityki zagranicznej, aczkolwiek co równie ważne, stwarza równoległe możliwości działania o charakterze autokreacyjnym w stosunku do najbliższego środowiska międzynarodowego. Zaangażowanie proeuropejskie rządu w Kijowie za pośrednictwem Unii Europejskiej i Stanów Zjednoczonych może spowodować, iż polityka zagraniczna Ukrainy będzie określana (postrzegana) i realizowana jako prozachodnia, nie zaś jednoznacznie jako prorosyjska (antyzachodnia). W podobnej konwencji Z. Brzeziński wysunął tezę, iż rdzeń bezpieczeństwa europejskiego w XXI w. powinien być konstytuowany według linii geostrategicznej: Paryż - Berlin - Warszawa - Kijów. Dlatego też niezwykle ważny pozostaje problem efektywnego wsparcia władz politycznych Ukrainy w procesie budowania demokratycznego i suwerennego państwa, co z kolei powinno skutkować powstrzymywaniem (normalizacją) Rosji w jej neoimperialnej polityce zagranicznej. Ukraina w procesie kreowania swojej polityki zewnętrznej powinna, zdaniem Brzezińskiego, przyjąć rolę tzw. „sworznia geopolitycznego” (geopolitical pivots), czyli państwa, które ze względu na swoje unikalne położenie geopolityczne może wpływać na stabilność lub jej brak w wymiarze regionalnego i globalnego środowiska międzynarodowego. Por.: Z. Brzeziński, Wielka szachownica. Gtówne cele polityki amerykańskiej, przeł. T. Wyżyński, Warszawa 1998, s. 56; T. Kapuśniak, Ukraina jako obszar wptywów międzynarodowych po zimnej wojnie, Warszawa-Lublin 2008.

35 A. Szeptycki, Ukraina wobec Rosji..., s. 426.

36 I. Kobrinska, Dtugi koniec zimnej wojny. Rosja i Europa Środkowa 1991-1996, przeł. E. Kornowska-Michalska, Warszawa 1998, s. 40-44. 
w Kijowie proklamowała niepodległość państwa ukraińskiego. Następnie 1 grudnia 1990 r. 90\% obywateli Ukrainy opowiedziało się za proklamowaniem suwerennego państwa. Ukraina Felix, o której tak sugestywnie perorował Taras Szewczenko, stała się zatem geopolitycznym faktem i politycznomiędzynarodowym wyzwaniem (dla Federacji Rosyjskiej i sąsiadów Ukrainy) ${ }^{37}$. Innymi słowy, geopolityczna zmiana w postaci powstania niepodległej Ukrainy miała i ma szczególne znaczenie dla całego środowiska międzynarodowego Europy Środkowo-Wschodniej i nieustannie jest szansą/ wyzwaniem ukształtowania korzystnego - z perspektywy geopolitycznych preferencji poszczególnych państw - porządku międzynarodowego w tym regionie. Równolegle jednakże niepodległa Ukraina stała się wyzwaniem/dylematem dla polityki zagranicznej Federacji Rosyjskiej, traktującej nowo powstałe państwo ukraińskie jako integralną część tzw. obszaru poradzieckiego i strefę swoich wyłącznych geopolitycznych wpływów $^{38}$. Najważniejszą cechą polityki zagranicznej Ukrainy stało się w konsekwencji przyjęcie polityki faktycznego balansowania między najważniejszymi sąsiadami (w ramach przyjętego modelu wielowektorowości): Rosją z jednej a Unią Europejską i NATO z drugiej strony. Istotną rolę odgrywały również relacje ze Stanami Zjednoczonymi, Rzeczpospolitą Polską oraz wybranymi państwami azjatyckimi (Chiny, wybrane państwa Azji Środkowej) $)^{39}$.

Jak konstatuje Szeptycki, Federacja Rosyjska od rozpadu ZSRR dąży (dążyła) w swoich działaniach do efektywnej reintegracji obszaru poradzieckiego bądź też jego określonej części. Cel ten władze rosyjskie starają (starały) się realizować za pośrednictwem preferowanych form współpracy politycznej, ekonomicznej, społeczno-kulturalnej i militarnej implementowanej w płaszczyznach bilateralnej i multilateralnej (np. Wspólnoty Niepodległych Państw, Wspólnej Przestrzeni Gospodarczej, Unii Celnej i w przyszłości potencjalnie - Eurazjatyckiej Unii Gospodarczej). Kluczowym adresatem tych propozycji pozostaje Republika Ukrainy.

W tym kontekście należy podkreślić, iż polityka zagraniczna Ukrainy analizowana w całościowy sposób nie jest jednoznacznie i na trwałe zależna od Rosji. Po pierwsze, Ukraina (społeczeństwo ukraińskie) chce być postrzegana jako liczące się, niezależne od Rosji państwo europejskie. Dała temu niejednokrotnie wyraz, zarówno w okresie „pomarańczowej rewolucji” 2004 r., jak również tzw. „rewolucji godności” 2013/2014 r. Po drugie, władze ukraińskie de facto nigdy nie zaakceptowały rosyjskich dążeń i planów związanych z ich państwem. Ukraina przystąpiła do niektórych struktur współtworzonych przez Federację Rosyjską, aczkolwiek jej uczestnictwo w praktyce dopro-

Jeżeli przyjmiemy, iż geopolityka jest nauką o zastosowaniu zasad geografii do polityki międzynarodowej, to stwierdzimy, iż różne aspekty czynników geograficznych wpływają na historię, także tę współczesną, a pośrednio kształtują również politykę państw w środowisku międzynarodowym. W nauce o stosunkach międzynarodowych rozpowszechniony jest pogląd o istotnym znaczeniu czynników geograficznych, które warunkują treść i kierunki rozwoju polityk zagranicznych poszczególnych państw. J. Frankel, The Making of Foreign Policy. An Analysis of Decisionmaking, London 1963, s. 57-61.

38 Por.: M. Pietraś, M. Malskyj, B. Surmacz, Wstęp, [w:] Stosunki polsko-ukraińskie 1991-2014. Próba bilansu, red. ciż, Lublin 2016, s. 9.

39 A. Szeptycki, Ukraina wobec Rosji..., s. 377. 
wadziło do ich funkcjonalnego paraliżu. W tym obszarze wysiłki Rosji zmierzające do silniejszego podporządkowania sobie Ukrainy faktycznie nie powiodty się (Rosji nie udało się nakłonić Ukrainy do włączenia się do kolejnych projektów reintegracyjnych realizowanych na obszarze poradzieckim). Ukraina opowiadała się za rozwojem dobrosąsiedzkich stosunków i „strategicznego partnerstwa” z Rosją i innymi państwami poradzieckimi, przy zastrzeżeniu braku rosyjskich dążeń do reintegracji tego obszaru i zapewnienia FR szczególnej i uprzywilejowanej pozycji w regionie ${ }^{40}$. Co więcej, władze ukraińskie podejmowały działania na rzecz rozwoju na obszarze byłego ZSRR alternatywnych wobec rosyjskich regionalnych struktur współpracy. Innymi słowy, Ukraina w sposób świadomy dążyła również do ograniczenia dominacji Federacji Rosyjskiej na obszarze dawnego ZSRR poprzez rozwój współpracy z innymi państwami, krytycznie bądź sceptycznie odnoszącymi się do polityki realizowanej przez $\mathrm{FR}^{41}$.

Można zatem sądzić, że Federacja Rosyjska akceptowała (akceptuje) specyfikę ukraińskiej polityki zagranicznej, o ile - w mniemaniu Moskwy - nie ma ona jednoznacznie antyrosyjskiego charakteru. Co najistotniejsze, kwestia faktycznej zależności (dependencji) między oboma państwami ujawnia się przede wszystkim w określonych i istotnych z perspektywy Ukrainy i Rosji obszarach. Należą do nich współpraca na obszarze byłego ZSRR (odbudowanie przez FR więzów zależności pomiędzy państwami poradzieckimi) i stosunki z państwami zachodnimi, w szczególności współpraca Ukrainy z UE i NATO. I tak, zarówno Rosja, jak i Ukraina realizują intensywny dialog polityczny z państwami zachodnimi, w szczególności NATO (np. Rada Rosja-NATO; Komisja NATO-Ukraina) i Unią Europejską. Federacja Rosyjska pragnie jednakże zachować status głównego partnera i swoistego ,interlokutora” dla państw zachodnich na obszarze byłego ZSRR. Ma temu służyć polityka dezintegracji terytorialnej państwa ukraińskiego (politique du fait accompli), podejmowana w ramach procesu tzw. aneksji Krymu i „zamrożonych” konfliktów w regionie Republik Donieckiej i Ługańskiej, podtrzymywanie w państwach zachodnich negatywnych stereotypów dotyczących Ukrainy i jej

40 Federacja Rosyjska od rozpadu ZSRR przywiązuje szczególną wagę do obszaru byłego Związku Radzieckiego, znanego w rosyjskim dyskursie jako „bliska zagranica”. Jego znaczenie z perspektywy Rosji wynika z bezpośredniego geopolitycznego sąsiedztwa, obecności w regionie mniejszości rosyjskiej i ludności rosyjskojęzycznej, wyzwań płynących z krajów „bliskiej zagranicy” dla FR, roli powiązań gospodarczych. W opinii Rosji jej działania na rzecz reintegracji obszaru poradzieckiego, zwłaszcza na płaszczyźnie ekonomicznej, są całkowicie uzasadnione, biorąc pod uwagę specjalną rolę, jaką Federacja Rosyjska odgrywa w regionie jako czynnik stabilizujący i tzw. rzecznik reform. W praktyce koncepcja „bliskiej zagranicy” nie ogranicza się do dobrowolnej współpracy gospodarczej, ale ma wymiar imperialny. Relacje FR z pozostałymi państwami regionu mają charakter silnie asymetryczny, zaś Rosja dąży do umocnienia swojej dominacji na obszarze byłego ZSRR. Cel ten stara się osiągnąć m.in. poprzez stworzenie regionalnego systemu bezpieczeństwa zbiorowego, zapobieganie konfliktom na tym obszarze i ich rozwiązywanie (tzw. „zamrożone” konflikty), stabilizację przestrzeni poradzieckiej oraz integrację polityczną i gospodarczą. Rosja nie dysponuje odpowiednim potencjałem, aby efektywnie zrealizować zamierzone cele. Jej politykę cechuje natomiast duża elastyczność - stąd kolejne proponowane przez nią projekty integracyjne, które mają zastąpić bądź uzupełnić wcześniejsze, z reguły ograniczające się tylko do deklaracji politycznych. A. Szeptycki, Ukraina wobec Rosji..., s. 380; por.: Rosja. Rozważania imperiologiczne, red. S. Bieleń, A. Skrzypek, Warszawa 2015.

$41 \quad$ A. Szeptycki, Ukraina wobec Rosji..., s. 378, 380, 426-427. 
polityki wewnętrznej i zagranicznej, przedstawiających ją jako państwo niestabilne, niewiarygodne i ściśle powiązane z Rosją (wspólna tożsamość kulturowo-cywilizacyjna i konfesyjna, kultura polityczna, uzależnienie Ukrainy od potencjału surowcowego FR etc. $)^{42}$. Władze rosyjskie nie chcą zatem, aby współpraca Ukrainy z instytucjami zachodnimi przekroczyła jasno wyznaczone przez władze Rosji granice: w przypadku Sojuszu Północnoatlantyckiego chodzi o objęcie Ukrainy Planem Działań na rzecz Członkostwa ${ }^{43}$; w przypadku UE - realizację postanowień umowy stowarzyszeniowej, przewidującej ustanowienie pogłębionej i kompleksowej strefy wolnego handlu Ukraina-UE i być może pełną integrację Ukrainy z UE in spe. Aby osiągnąć ten cel, Rosja wkorzystuje instrumenty, jakimi dysponuje, w odniesieniu zarówno do ukraińskich władz i społeczeństwa, jak również bezpośrednio w państwach zachodnich. Ten ostatni element jest szczególnie interesujący - pokazuje bowiem, że zależność Ukrainy od Rosji warunkowana jest również relacjami obu państw z podmiotami trzecimi (państwa, organizacje międzynarodowe $)^{44}$.

W tym kontekście należy zwrócić uwagę, iż wydarzenia potocznie określane mianem „rewolucji Euromajdanu” doprowadziły do jednej z bardziej gwałtownych przemian nie tylko w przestrzeni posowieckiej, ale też w całej kontynentalnej Europie. Dodatkowo działania Federacji Rosyjskiej destabilizujące sytuację we wschodniej części Ukrainy i anektowanie Krymu niewątpliwie stanowią największy kryzys bezpieczeństwa europejskiego od czasu wojny bałkańskiej w latach 90. Nikt nie spodziewał się, że kiedy w listopadzie 2013 r. prezydent Janukowycz wstrzymał proces zbliżania się do Unii Europejskiej, zapoczątkował wewnętrzny kryzys w tym państwie, mający poważne strategiczne konsekwencje dla całej Europy. Sama Rosja w „konkurencji” z Unią Europejską o Ukrainę nie zawahała się podjąć typowych dla niej środków z zakresu tzw. twardej polityki (hard power). W konsekwencji ewolucja i rozwój kryzysu ukraińskie-

42 Zgodnie z tezą amerykańskiego politologa S. Huntingtona wyrażoną w jego książce Zderzenie cywilizacji i nowy ksztatt tadu światowego, należy zauważyć, iż Ukraina wydaje się tzw. państwem rozszczepionym (cleft country), którego szanse egzystencjalne stanowią funkcję jego zagrożenia zewnętrznego, generowanego przede wszystkim przez Federację Rosyjską. Rosja z kolei postrzega Ukrainę jako geopolityczną efemerydę, która bez jej poparcia nie jest zdolna do samodzielnego istnienia. Por.: S. Huntington, Zderzenie cywilizacji i nowy ksztatt tadu światowego, przeł. H. Jankowska, Warszawa 2003, Spectrum.

43 Na problem złożoności stosunków w triadzie podmiotów Ukraina-NATO-Rosja oraz kierunków ich ewolucji w przyszłości zwróciło uwagę dwóch wielkich luminarzy amerykańskiej polityki zagranicznej - Z. Brzeziński i H. Kissinger. W istocie w swoich rozważaniach wysunęli koncepcję tzw. „finlandyzacji Ukrainy", tj. przyznania Ukrainie możliwości polityczno-gospodarczej integracji z Zachodem (np. w ramach akcesji do UE) przy jednoczesnym pozbawieniu jej perspektywy przystąpienia do Sojuszu Północnoatlantyckiego. Por.: H. Kissinger, To Settle the Ukraine Crisis, Start at the End, „The Washington Post” 2014, 5 III, [online] https://www.washingtonpost.com/opinions/henrykissinger-to-settle-the-ukraine-crisis-start-at-the-end/2014/03/05/46dad868-a496-11e3-8466d34c451760b9_story.html, 10 X 2015; Z. Brzeziński, Russia and Ukraine, Statement before the Senate Foreign Relations Committee, 9 VII 2014, [online] http://csis.org/testimony/russia-and-ukraine, 10 X 2015; M. Czech, 2014, 10 III, [online] http://wyborcza.pl/1,75968,15595411,Henry_Kissinger_nie_ma_racji_Ukraina_to_nie_Finlandia.html, 10 X 2015.

$44 \quad$ A. Szeptycki, Ukraina wobec Rosji..., s. 426. 
go, w tym ewentualna destabilizacja innych regionów poprzez działania inspirowane przez Rosję, miałyby zależeć od akceptacji przez Ukrainę postulatów Rosji, które są jednoznacznie rozbieżne i asymetryczne. Ich krytycznym punktem wydaje się chęć Rosji dalszego pogłębiania stanu dysfunkcji i dependencji Ukrainy od FR, poprzez np. rosyjskie żądania zmiany ustroju Ukrainy na federalny, ze znaczącą autonomią dla obwodów wschodnich i południowych, włącznie z prawem do podpisywania przez nie umów międzynarodowych. Zachód (Unia Europejska i Stany Zjednoczone), jak wiadomo, w reakcji na opisywane wydarzenia podjął próbę mediacji mającą na celu doprowadzenie do „deeskalacji” konfliktu na Ukrainie, w ramach tzw. formatów genewskiego i normandzkiego ${ }^{45}$.

Jak wspomniano uprzednio, zależność Ukrainy od Rosji warunkowana jest relacjami obu państw z podmiotami trzecimi (UE, USA, NATO etc.) - po wydarzeniach „rewolucji godności” przede wszystkim z Unią Europejską. Należy zatem podkreślić, iż skuteczność polityki wschodniej UE pozostaje uwarunkowana szeregiem czynników i zmiennych o charakterze wewnątrzeuropejskim (polityczno-instytucjonalnym) i zewnętrznym. Wydarzenia, do jakich doszło w ostatnich latach wewnątrz Unii Europejskiej, ale również w jej najbliższym otoczeniu międzynarodowym, nie pozostają bez wplywu na treść polityki Wspólnoty wobec sąsiadów, realizowanej w ramach mechanizmu Europejskiej Polityki Sąsiedztwa (np. Partnerstwo Wschodnie, Partnerstwo Śródziemnomorskie, Synergia Czarnomorska). Należy zatem wspomnieć o presji takich uwarunkowań, jak: kryzys w strefie euro, problem renegocjacji uczestnictwa Wielkiej Brytanii w UE („Brexit”), konflikt wewnętrzny w Syrii, problem migracji i uchodźstwa wewnątrz UE, nasilające się zjawisko terroryzmu w Europie, neoimperialna polityka Federacji Rosyjskiej (aneksja Krymu i tzw. „wojna hybrydowa” w południowej i wschodniej części Ukrainy etc). Wymienione czynniki generują i wpływają na powstanie faktycznego podziału politycznego pomiędzy państwami członkowskimi UE, istotnego z punktu widzenia zachowania spójności strategii międzynarodowej realizowanej przez Wspólnotę według tzw. klucza geograficznego na: 1) państwa zainteresowane sprawami związanymi z regionem Morza Śródziemnego (państwa Południa oraz państwa docelowe dla olbrzymiej liczby migrantów: Niemcy, Austria etc.) oraz 2) państwa skupione na sytuacji we wschodnim sąsiedztwie UE (Polska, szerzej Europa Środkowa, państwa bałtyckie, Szwecja), dla których wojna Rosji z Ukrainą stwarza bezpośrednie wyzwanie dla ich bezpieczeństwa, jak również dla całego regionu Europy Środkow-Wschodniej ${ }^{46}$.

Wobec powyższego należy skonstatować, iż w strukturze wewnętrznej UE występują państwa, które można roboczo określić mianem grupy państw zainteresowanych pogłębianiem współpracy z państwami Europy Wschodniej, tj. z Ukrainą (państwa bałtyckie i państwa V4). To na tej grupie spoczywa de facto największy obowiązek podtrzy-

45 B. Piskorska, Między retoryką a rzeczywistościa: relacje Ukrainy z Unią Europejska w kontekście kryzysu na Ukrainie 2013/2014, [w:] Stosunki polsko-ukrainskie 1991-2014..., s. 223, 242-243.

46 Por.: T. Stępniewski, Unia Europejska, Ukraina i Rosja: kryzysy i bezpieczeństwo, „Studia Europejskie” 2015, nr 4, s. 13. 
mywania politycznego wsparcia UE dla procesów europeizacji w Europie Wschodniej, skutecznego pozyskiwania środków na ich finansowanie oraz przekonania wschodnich sąsiadów do potrzeby wdrażania niezbędnych reform polityczno-ustrojowych i gospodarczych ${ }^{47}$. Osobną grupę stanowią przedstawiciele tych państw, dla których stosunki z regionem Europy Wschodniej stanowią wypadkową relacji zachodzących pomiędzy UE a Federacją Rosyjską i realizowanych niejako „w cieniu” Rosji (tzw. filozofia stosunków Russia first $)^{48}$.

W tym miejscu należy uwypuklić, iż znamienna i decydująca wydaje się w strukturze państw członkowskich UE pozycja i rola Republiki Niemieckiej. Nie ulega wątpliwości, iż w warunkach zaistniałego kryzysu w strefie euro oraz kryzysu ukraińskiego nastąpiła faktyczna zmiana „politycznego układu sił” wewnątrz Unii Europejskiej, w ramach którego naturalnym liderem Wspólnoty stała się Republika Federalna ${ }^{49}$. W konsekwencji doszło również do zmiany „paradygmatu” polityki zagranicznej samych Niemiec wobec państw Europy Wschodniej, jak również strategii UE wobec całego regionu Europy Środkowo-Wschodniej. Jak zauważył Ulrich Speck, kryzys ukraiński pokazat, że przywództwo Niemiec nie organiczna sie jedynie do wewnętrznych spraw UE, gdzie Niemcy zawsze byty ważnym graczem. Berlin obecnie mówi i dziata w coraz większym stopniu w imieniu catej UE w sprawach zagranicznych, przynajmniej jeśli chodzi o stosunki UE zjej wschodnimi sasiadami ${ }^{50}$. Zdaniem Specka doszło do wzrostu znaczenia i siły Niemiec wewnątrz Wspólnoty, co również koresponduje z faktem, iż większość państw konstytuujących tzw. „Nową Europę” (New Europe) postrzega Niemcy jako naturalnego lidera ${ }^{51}$.

Ponadto warto zauważyć, iż opisywany podział wewnętrzny w strukturze państw członkowskich UE odnośnie do sytuacji na Ukrainie i reakcji na politykę Rosji wobec Ukrainy charakteryzuje się nieco odmiennym przebiegiem aniżeli dotychczas. Do tej pory podział ten przebiegał w ramach wewnętrznej dychotomii Wschód-Zachód. Obecnie odpowiada zdecydowanie podziałowi UE na Północ i Południe (kryzys w strefie euro opisywaną dychotomię jeszcze wyraźniej uwydatnił). Państwa północne, włączając również państwa bałtyckie oraz większość państw Europy Środkowej i Wschodniej, postrzegają Rosję niezmiennie jako zagrożenie. Wydaje się zatem, iż z punktu widzenia skuteczności polityki Wspólnoty wobec problemu proeuropejskiej przyszłości Ukrainy i ograniczania neoimperialnej polityki Federacji Rosyjskiej decydujące znaczenie będą miały czynniki spoistości, jednolitości i koherencji polityki UE wobec tzw.

47 T. Stępniewski, T. Olejarz, Wyzwania Unii Europejskiej na wschodzie Europy, „Studia Europejskie” 2011, nr 2, s. 161.

Por.: T. Kapuśniak, Ukraina jako obszar wptywów...

49 P. Buras, Dylematy państwa status quo. Nowa kwestia niemiecka w Europie, „Sprawy Międzynarodowe” 2014, R. 67, nr 4, s. 131.

50 U. Speck, Power and Purpose. German Foreign Policy at a Crossroads, Carnegie Europe, 3 X 2014, [online] http://carnegieeurope.eu/2014/11/03/power-and-purpose-german-foreign-policy-at-crossroads, $10 \times 2015$.

51 Tamże; por.: R. Sikorski, Polska i przysztość Europy, Berlin, 28 XI 2011, [online] http://msz.gov.pl/ resource/c2a33d88-7b8d-4fa5-8680-a67a4b2b38af:JCR, 10 X 2015. 
Wschodu ${ }^{52}$. Jak zauważa Judy Dempsey, a strong Europe means having a coherent and united foreign, security and defence policy. Europe lacks these three essential elements that would make Europe think and act strategically. Without them, Europe is weak ${ }^{53}$.

\section{PODSUMOWANIE}

$\mathrm{Z}$ analizy charakterystyki zjawisk dysfunkcji i dependencji Ukrainy w środowisku wewnątrzpaństwowym i międzynarodowym jasno wynika, iż w dalszym ciągu aktualny pozostaje dylemat, na ile na Ukrainie mamy do czynienia ze zjawiskiem konsolidacji prawdziwie liberalnej demokracji, a na ile zaś z jej nieliberalną (hybrydalną) odmianą. W dyskursie politologicznym dominuje bowiem pogląd, iż niepodległą Ukrainę należy uznać za specyficzną odmianę tzw. „państwa hybrydowego”. Dla państwa hybrydowego differentia specifica jest połączenie pozostałości starego systemu autorytarnego z liberalnymi instytucjami gospodarczymi i politycznymi. Co więcej, w takim państwie proces polityczny charakteryzuje się zastojem, korupcją i dominującą rolą elit, które przynoszą państwu mało korzyści i dysponują znikomym poparciem społecznym. Dodatkowo na Ukrainie zauważalne są także: znikomy poziom reprezentacji interesów społecznych przez instytucje państwa; niski stopień politycznego zaangażowania społeczeństwa i jego udziału w życiu społecznym w okresie pomiędzy wyborami; brak szacunku dla reguł państwa prawa; niski poziom legitymacji społecznej w procesach wyborczych; znikomy stopień zaufania społeczeństwa do instytucji państwa; ogólnie niedoskonałe funkcjonowanie aparatu państwowego.

Należy zatem przyjąć, iż dotychczasowe procesy transformacyjne, jakie dokonują się na Ukrainie, nie powinny być rozpatrywane w płaszczyźnie liniowej. Tym samym właściwsze pozostaje określenie ich charakteru z perspektywy ich złożoności i wieloaspektowości. Taka percepcja związana jest ze zmianami, jakie zachodzą wewnątrz instytucji życia politycznego w kierunku ich pełniejszej demokratyzacji, przy równoległym uwzględnieniu tendencji przeciwstawnych, tj. ukierunkowanych na zachowanie i petryfikację tendencji antydemokratycznych.

Inaczej rzecz ujmując, ewolucję ustroju polityczno-ustrojowego na Ukrainie w latach 1991-2015 należy rozpatrywać przez pryzmat równolegle dokonujących się procesów demokratyzacji (europeizacji?) i dysfunkcji państwa ${ }^{54}$. Przezwyciężanie istniejących zależności (dependencji) w obecnej fazie rozwoju państwa ukraińskiego wymagałoby przede wszystkim: wprowadzenia na Ukrainie rozwiązań ustrojowych zgodnych ze standardami europejskimi (procesy europeizacji); ograniczenia zależności Ukrainy od Federacji Rosyjskiej w sferach pozapolitycznych (procesy emancypacji),

52 Part of the problem that we have today is that we take the European Union for granted. The more we do this, the higher the risk of its disintegration. The belief that something cannot collapse leads to high-risk behavior - I. Krastev, How to Avoid Europe’s Disintegration, „New Eastern Europe” 2015, nr 5, s. 8.

53 J. Dempsey, Doubletake. Does Russia Divide Europe?, „New Eastern Europe” 2015, nr 5, s. 23.

54 Por.: T. Olejarz, T. Stępniewski, Ukraina między dysfunkcjonalną demokracją..., s. 64; ciż, Yкpauнa между дисфункциёнальной демократией..., s. 102-103. 
dzięki czemu współpraca ukraińsko-rosyjska uległaby normalizacji, zaś sama Rosja nie mogłaby wykorzystywać istniejących zależności jako instrumentu nacisku na władze Ukrainy; zmiany polityki Federacji Rosyjskiej w odniesieniu do Ukrainy, w szczególności poszanowania przez Rosję podstawowych zasad prawa międzynarodowego, takich jak suwerenna równość i nieingerencja w sprawy wewnętrzne Ukrainy 55 .

W środowisku wewnątrzpolitycznym państwa ukraińskiego dalsza droga tego podmiotu w kierunku skonsolidowanej demokracji wydaje się w dalszym ciągu otwarta, aczkolwiek uwarunkowana: zdolnością elit politycznych do konstruktywnej współpracy; konsekwentną realizacją niezbędnych reform politycznych; pogłębianiem współpracy Ukrainy ze strukturami euroatlantyckimi; rozwojem społeczeństwa obywatelskiego ${ }^{56}$.

\section{BIBLIOGRAFIA}

The African Studies Centre, The Transnational Institute, The Peace Studies Group, The Peace

Research Center-CIP/FUHEM, Failed and Collapsed States in the International System, Leiden-Amsterdam-Madrid 2003.

Åslund A., How Ukraine Became a Market Economy and Democracy, Washington 2009.

Åslund A., Proposals for Ukraine: 2010 - Time for Reforms, Independent International Experts

Commission, Kyiv 2010, Peterson Institute for International Economics, 18 II 2010, [on-

line] http://www.piie.com/events/event_detail.cfm?EventID=140.

Bieleń S., Pañstwa upadte, [w:] Organizacja Narodów Zjednoczonych. Bilans i perspektywy, red. J. Symonides, Warszawa 2006.

Bieleń S., Państwa w stanie kryzysu i upadku?, [w:] Państwo w teorii i praktyce stosunków międzynarodowych, red. M. Sułek, J. Symonides, Warszawa 2009.

Brzeziński Z., Russia and Ukraine, Statement before the Senate Foreign Relations Committee,

9 VII 2014, [online] http://csis.org/testimony/russia-and-ukraine.

Brzeziński Z., Wielka szachownica. Gtówne cele polityki amerykańskiej, przeł. T. Wyżyński, Warszawa 1998.

Buras P., Dylematy państwa status quo. Nowa kwestia niemiecka w Europie, „Sprawy Międzynarodowe" 2014, R. 67, nr 4 .

Cooper R., Pękanie granic: Porzadek i chaos w XXI wieku, przeł. P. Kłossowicz, Poznań 2005.

Croker Ch., Engaging Failing States, „Foreign Affairs” 2003, Vol. 82, nr 5.

Czech M., Henry Kissinger nie ma racji. Ukraina to nie Finlandia, „Gazeta Wyborcza” 2014,

10 III, [online] http://wyborcza.pl/1,75968,15595411,Henry_Kissinger_nie_ma_racji_ Ukraina_to_nie_Finlandia.html.

Dempsey J., Doubletake. Does Russia Divide Europe?, „New Eastern Europe” 2015, nr 5.

55 A. Szeptycki, Ukraina wobec Rosji..., s. 174.

56 Por.: T. Olejarz, T. Stępniewski, Ukraina między dysfunkcjonalna demokracją..., s. 64; ciż, Укpauнa между дисфункииёнальной демократией..., s. 103; A. Åslund, Proposals for Ukraine: 2010 - Time for Reforms, Independent International Experts Commission, Kyiv 2010, Peterson Institute for International Economics, 18 II 2010, [online] http://www.piie.com/events/event_detail.cfm?EventID=140, $10 \times 2015$. 
Fedorowicz K., Ukraińskie rewolucje a parlamentaryzm, „Rocznik Instytutu Europy Środkowo-Wschodniej” 2014, R. 12, z. 2: Majdan 2014: Ukraina na rozdrożu.

Frankel J., The Making of Foreign Policy. An Analysis of Decisionmaking, London 1963.

Fukuyama F., Budowanie państwa. Wtadza i tad międzynarodowy w XXI wieku, przeł. J. Serwański, Poznań 2005.

Ghani A., Lockhart C., Fixing Failed States. A Framework for Rebuilding A Fractured World, New York 2008.

Gil G., Ewolucja funkcji państwa w późnowesfalskim tadzie międzynarodowym, [w:] Późnowestfalski tad międzynarodowy, red. M. Pietraś, K. Marzęda, Lublin 2008.

Hughes J., Transition Models and Democratisation in Russia, [w:] Russia after the Cold War, red. M. Bowker, C. Ross, Harlow 2000.

Huntington S., Zderzenie cywilizacji i nowy ksztatt tadu światowego, przeł. H. Jankowska, Warszawa 2003, Spectrum.

Jekaterynczuk A., Kogo reprezentowat kijowski Majdan 2013-2014? Struktura spoteczno-demograficzna i kulturowa kijowskiego Euromajdanu w Kijowie, oczekiwania oraz ewolucja. Socjologiczny obraz kijowskiego Majdanu z końca 2013 - początku 2014 roku, ,Rocznik Instytutu Europy Środkowo-Wschodniej” 2014, R. 12, z. 5: Rosja Putina-Ukraina-Europa: geopolityka, bezpieczeństwo, gospodarka.

Kaplan R., Coming Anarchy, „The Atlantic” 1994, nr 2.

Kaplan R., The Coming Anarchy. Shattering the Dreams of the Post Cold War, New York 2000.

Kapuśniak T., Ukraina jako obszar wptywów międzynarodowych po zimnej wojnie, WarszawaLublin 2008.

Kissinger H., To Settle the Ukraine Crisis, Start at the End, „The Washington Post” 2014, 5 III, [online] https://www.washingtonpost.com/opinions/henry-kissinger-to-settle-the-ukraine -crisis-start-at-the-end/2014/03/05/46dad868-a496-11e3-8466-d34c451760b9_story. html.

Kobrinska I., Dtugi koniec zimnej wojny. Rosja i Europa Środkowa 1991-1996, przeł. E. Kornowska-Michalska, Warszawa 1998.

Kondrakiewicz D., Państwo, [w:] Międzynarodowe stosunki polityczne, red. M. Pietraś, Lublin 2006.

Konończuk W., Olszański T., Co Majdan mówi o Ukrainie? Diagnoza i perspektywy ukraińskiej polityki, 17 I 2014, Komentarze OSW, nr 125, [online] http://www.osw.waw.pl/pl/publi kacje/komentarze-osw/2014-01-17/co-majdan-mowi-o-ukrainie-diagnoza-i-perspektywy -ukrainskiej.

Krastev I., How to Avoid Europe's Disintegration, „New Eastern Europe” 2015, nr 5.

Kulesa Ł., Tarnogórski R., Przysztość ONZ - reinterpretacja czy zmiana Karty Narodów Zjednoczonych?, „Polski Przegląd Dyplomatyczny” 2005, t. 5, nr 1.

Kuźniar R., Polityka i sita. Studia strategiczne - zarys problematyki, Warszawa 2005.

Macijewskij J., Między autorytaryzmem i demokracją: ustrój polityczny w Ukrainie po „pomarańczowej rewolucji”, „Nowa Ukraina” 2008, nr 1-2.

Milewski J., Państwo w Afryce: dylematy i kierunki przeobrażeń, [w:] Stosunki międzynarodowe $w$ Afryce, red. J. Milewski, W. Lizak, Warszawa 2002. 
Olejarz T., Stępniewski T., Ukraina między dysfunkcjonalna demokracja a nieskonsolidowanym autorytaryzmem, Lublin 2011, Prace Instytutu Europy Środkowo-Wschodniej, 23.

Olejarz T., Stępniewski T., Украина между дисфункциёнальной демократией а несконсолидированньм авторитаризмом, [w:] Перед въьбором. Будущее Украины в условиях системной дестабилизачии, red. А. Гиль, Т. Стемпневски, Lublin 2013.

Pietraś M., Malskyj M., Surmacz B., Wstęp, [w:] Stosunki polsko-ukraińskie 1991-2014. Próba bilansu, red. ciż, Lublin 2016.

Pietraś Z.J., Polityka zagraniczna państwa, [w:] Wspótczesne stosunki międzynarodowe, red. T. Łoś-Nowak, Wrocław 1997.

Piotrkowski M., Uwarunkowania oraz konsekwencje rozktadu i rozpadu struktur państwowych, [w:] Pótnoc wobec Potudnia, Potudnie wobec Pótnocy, red. M.W. Solarz, Warszawa 2005.

Piskorska B., Między retoryka a rzeczywistością: relacje Ukrainy z Unia Europejska w kontekście kryzysu na Ukrainie 2013/2014, [w:] Stosunki polsko-ukraińskie 1991-2014. Próba bilansu, red. M. Pietraś, M. Malskyj, B. Surmacz, Lublin 2016.

Potocki R., Państwo dysfunkcyjne w perspektywie geopolitycznej, Geopolityka.org, 13 II 2011, [online] http://www.geopolityka.org/analizy/robert-potocki-panstwo-dysfunkcyjne-wperspektywie-geopolitycznej.

Potocki R., Problem rekonstrukcji państw dysfunkcyjnych na peryferiach systemu światowego po 11 września 2001 r., [w:] Pótnoc wobec Potudnia, Potudnie wobec Pótnocy, red. M.W. Solarz, Warszawa 2005.

Potocki R., Kocoń M., Państwo dysfunkcyjne w środowisku międzynarodowym, [w:] Państwo w świecie wspótczesnym, red. K. Trzciński, Warszawa 2006.

Riabow A., Rosja i Ukraina - dwa alternatywne modele transformacji postkomunistycznej?, [w:] Rosja: jak żyć z Ukraina? Ukraina: jak żyć z Rosją? Stosunki ukrainsko-rosyjskie w 2006 roku i w najbliższej przysztości, red. W. Konończuk, Warszawa 2006.

Roman Ł., Państwa upadte jako zagrożenie bezpieczeństwa na początku XXI wieku, „Obronność. Zeszyty Naukowe Wydziału Zarządzania i Dowodzenia AON”2014, nr 3.

Rosja. Rozważania imperiologiczne, red. S. Bieleń, A. Skrzypek, Warszawa 2015.

Rotberg R., The Failure and Collapse of Nation-States. Breakdown, Prevention and Repair, [w:] When States Fail: Causes and Consequences, red. tenże, Princeton 2004.

Sikorski R., Polska i przysztość Europy, Berlin, 28 XI 2011, [online] http://msz.gov.pl/resource/ c2a33d88-7b8d-4fa5-8680-a67a4b2b38af:JCR.

Speck U., Power and Purpose. German Foreign Policy at a Crossroads, Carnegie Europe, 3 X 2014, [online] http://carnegieeurope.eu/2014/11/03/power-and-purpose-german-foreign-poli cy-at-crossroads.

Stępniewski T., Polityka bezpieczeństwa Ukrainy po 2010 roku, „Rocznik Instytutu Europy Środkowo-Wschodniej” 2013, R. 11, z. 2: Stowiański trójkąt: Rosja, Ukraina, Biatoruś.

Stępniewski T., Unia Europejska, Ukraina i Rosja: kryzysy i bezpieczeństwo, „Studia Europejskie” 2015, nr 4.

Stępniewski T., Olejarz T., Wyzwania Unii Europejskiej na wschodzie Europy, „Studia Europejskie" 2011, nr 2.

Szeptycki A., Ukraina wobec Rosji. Studium zależności, Warszawa 2013. 
Way L., Authoritarian State Building and the Source of Regime Competitiveness in the Fourth Wave: The Cases of Belarus, Moldova, Russia, and Ukraine, "World Politics” 2005, Vol. 57, nr 2, [online] http://dx.doi.org/10.1353/wp.2005.0018.

Włoch R., Funkcje polityki zagranicznej, [w:] Wstęp do teorii polityki zagranicznej państwa, red. R. Zięba, Toruń 2004.

Zajadło J., Prawo międzynarodowe wobec problemu „państwa upadtego”, „Państwo i Prawo” 2005, nr 2.

Полохало В., Політична арена Украйни, „Філософська і соціологічна думка” 1992, nr 4.

Полохало В., Політологія посткомуністичних суспільств в Україні та Росї, „Політична Аумка" 1998, nr 2.

Mgr Tomasz OLEJARZ - prawnik i politolog, doktorant w Zakładzie Stosunków Międzynarodowych Wydziału Politologii UMCS w Lublinie. Wykładowca i wicedyrektor w Instytucie Nauk Społecznych Państwowej Wyższej Szkoły Wschodnioeuropejskiej w Przemyślu. Jego zainteresowania badawcze koncentrują się wokół międzynarodowych stosunków politycznych i interreligijnych, teorii polityki zagranicznej państwa, prawa międzynarodowego oraz studiów wschodnich.

Dr hab. Tomasz STĘPNIEWSKI - politolog i prawnik, kierownik Katedry Studiów Wschodnich, Instytut Nauk Politycznych i Spraw Międzynarodowych, Wydział Nauk Społecznych, Katolicki Uniwersytet Lubelski Jana Pawła II oraz Instytut Europy Środkowo-Wschodniej w Lublinie. Jego zainteresowania badawcze koncentrują się wokół stosunków międzynarodowych na obszarze WNP, wpływu Rosji na sytuację państw poradzieckich, polityki wschodniej Unii Europejskiej oraz bezpieczeństwa europejskiego. Autor artykułów publikowanych w wielu czasopismach naukowych oraz publikacji książkowych, w tym monografii: Geopolityka regionu Morza Czarnego w pozimnowojennym świecie, Lublin-Warszawa 2011, s. 415. 